\title{
Exploring the Development of Social Intelligence of Students During University Years
}

\author{
Mushtaq Ahmad Malik ${ }^{*}$ \\ Faisal Siddique ${ }^{* *}$ \\ Syed Nasir Hussain ${ }^{* * *}$
}

\begin{abstract}
During university years students go through educational as well as social interactions and achieve manifold developments. The purpose of the study was to explore the development of social intelligence during university years among University students. The study was delimited to four year under graduate programs Bachelor of Science (BS) students of University of Sargodha. The cross-sectional study includes the students of BS programs $1^{\text {st }}$ semester and $7^{\text {th }}$ semester. Using multi-stage sampling technique, 560 students in total from seven department of the university were selected as the sample. Tromso Social Intelligence Scale (TSIS) with reliability coefficient (Cronbach Alpha) 0.75 was used. It was found that overall the development of social intelligence during university years was at good rate and statistically significant. The urban and rural backgrounds students and boarder and day scholar students reported equal level of social intelligence; whereas male students reported higher level of social intelligence than the female students. It is recommended that the universities may arrange seminars and group discussion to provide social interaction to students. University administration and teachers may arrange co-curricular activities and other social gatherings at inter-departmental and inter-university level.
\end{abstract}

Keywords: social intelligence, four year under graduate students, university education and demographic differences

\footnotetext{
* Assistant professor, Department of Education, University of Sargodha; Email: mushtaq.ahmad@uos.edu.pk

${ }^{* *}$ M. Phil Scholar, Department of Education, University of Sargodha

${ }^{* * *}$ Subject Specialist, GCET, Sargodha. (Currently lecturer, ECE \& ETED, Allama Iqbal Open University, Email: nasir.hussain@aiou.edu.pk)
} 


\section{Introduction}

It is need of every human to live in society. In any society, developing and maintaining social relations, meeting differences and facing conflicting views is a challenge to everyone. So, everyone needs to adjust himself / herself with others. She/he needs to use her/his abilities in understanding and managing others. She/he also needs to develop the skills of managing difficult situations in different social environments. Hence to live in the society one is to use her/his social intelligence (Lacanlale, 2013).

Social intelligence includes our abilities to understand others' behavior in terms of mental states. The mental states involve thoughts, behaviors, wishes, intentions, desires, and beliefs to interact in his environment. The environment or society includes both the complex social groups and close relationships groups. It predicts how others will feel, think, and behave. So, it is individual's bank of knowledge towards the social matters of the society (Sternberg, 2004; Habib, Saleem, \& Mahmood, 2013).

The concept of social intelligence was given very early in 1920 by Thorndike. He described that social intelligence is the ability to understand and manage others to act wisely in framing social relationship. Socially intelligent people are thought to be creative, with well communication skills and friendly (Buzan, 2002). Social intelligence is a broader term that highlights the construct including social skills, being intelligent in making relationship which has focus on the successful interactions with other persons (Hopkins \& Bilimoria, 2008). Social intelligence is strongly related to the norms of the society and it is difficult to compare social intelligence on different scales (Gini, 2006). Social intelligence is regarded as a function of a particular culture where the person lives (Dong, Koper, \& Collaco, 2008). In other words, behaviors and characteristics considered socially intelligent in one culture may not be considered socially intelligent in other culture. In different cultures, there may be different aims and objectives of the behaviors assumed as socially intelligent (Praditsang, Hanafi \& Walters, 2015).

The position of an adult in the network of relationships affects her/his future development (Laird, Jordan, Dodge, Pettit \& Bates, 2001). Adolescents with high status can solve many problems of their peers while adolescents having low social status remain at risk for solving the problems (Dodge \& Pettit 2003). Popular student is mostly pro-social 
and cooperative so she/he set the norms and values for behavior of interest in her/his peer group. She/he helps her/his peers in different fields of life and also helps them in their studies (Wang \& Ollendick, 2001; Lease, Kennedy \& Axelrod, 2002).

Adolescents' relationships with peers are linked with many sides of development and adjustment, and highly social adolescents earn many benefits because of their status in a number of ways. Determinants of high social intelligence or social status in the peer group improve the development of adolescents (Davis, 2010). They can solve their complex problems easily. According to Zins, Bloodworth, Weissberg \& Walberg (2004) there is a link between socio-emotional learning and school academic achievement. Moreover, a well-designed teaching program provides support to enhance the learning ability and socio-emotional intelligence of students (Seal, Naumann, Scott, \& Royce-Davis, 2011; Qualter, Whiteley, Morley \& Dudiak, 2009). Social intelligence is measured on the basis of three factors i.e. social information process, social skills and social awareness. Ability to realize verbal and non verbal communication is thought as Social Information Processing (SIP); Social Skills (SS) include the knowledge of basic communication skills and Social Awareness (SA) measures the behavior of the respondent in different situation of the society (Silvera, Martinussen \& Dahl, 2001).

Students who are socially strong can get better achievement in their study. They gain more ideas from their peers and society. They are selfmotivated from their society. They strive to establish their relations who are supportive and consistent with their personal interest and behavior (Ryan \& Patrick, 2001). In a learning environment, social skills are required in developing and maintaining positive relationships and managing disputes among students. Learning institutions are struggling more and more for developing social skill in their students. This will help them to perform better in their practical life (Hopkins \& Bilimoria, 2008).

The students entering into a new educational stage like college to university have to adjust themselves into a new administrative and academic environment and with new peers of different calibers with different socio economic and cultural background. As, university environment is very different than college environment (Parker \& Duffy, 2005; Davis, 2010) here they need to use their social intelligence. Students studying in lengthy programs interact with the peers and teachers. They make new friends and they may develop their social intelligence. Social intelligence develops with the passage of time. Social 
intelligence plays a positive role in academic achievement of students. Students who are socially strong may get better achievement (Robert, Wyer, \& Srull, 2013). So, it is needed to find out the development of social intelligence with the passage of time and interaction of new environment. Hence the problem opted for this study was to explore the development of social intelligence of students during university years.

\section{Objectives of the Study}

Objectives of the study were to explore the levels of social intelligence among university students studying in $1^{\text {st }}$ and $7^{\text {th }}$ semester.

The study would be important for university teachers to improve teacher student interaction so they would provide students learning environment, guide and improve their deficiencies in academic achievement. The university teachers may also develop social intelligence of university students for their personality development and academic success.

\section{Hypothesis of the Study}

Hypothesis of the study were:

$\mathrm{H}_{01}$ : There is no significant difference in the social intelligence of $1^{\text {st }}$ and $7^{\text {th }}$ semester students.

$\mathrm{H}_{02}$ : There is no significant difference between the social intelligence of male and female students.

$\mathrm{H}_{03}$ : There is no significant difference between the social intelligence of boarder and day scholar students.

$\mathrm{H}_{04}$ : There is no significant difference between the social intelligence of urban and rural areas students.

\section{Research Design}

In this study, a cross-sectional survey was conducted to explore the development of social intelligence of under graduate programs Bachelor of Science (BS) students studying in $1^{\text {st }}$ and $7^{\text {th }}$ semester during the university years. 


\section{Population and Sampling}

As the BS program is lengthy four years program, the study was delimited to the BS students of academic session of 2016-17. So, all the students of BS programs enrolled in the semester system of all the departments of University of Sargodha were included in the study. There are nine faculties at University of Sargodha; Faculty of Medical and Health Sciences does not offer semester system while Faculty of Engineering and Technology has been recently introduced and does not have the students of final semesters, so seven faculties were taken to draw the sample using multistage random sampling technique. Selecting one department from each faculty, seven departments were selected randomly. From each of these seven departments, 40 students, each of $1^{\text {st }}$ and $7^{\text {th }}$ semesters were selected randomly which made a sample of 560 students.

\section{Research Instruments}

To explore the social intelligence across university years, Tromso Social Intelligence Scale (TSIS) developed by Silvera, Martinussen, \& Dahl (2001) was adapted with permission. The instrument was made bilingual for better understanding of students consisting three factors and 21 items (seven items under each factor). There were eleven negative statements (Statement No. 2, 4, 5, 8, 11, 12, 13, 15, 16, 20 and 21) in the questionnaire. The response categories of the scale TSIS were strongly agreed, agreed, uncertain, disagreed and strongly disagreed. For numerical analyses, scores were allotted as 5, 4, 3, 2, and 1 respectively; while scoring was reversed for negative statements.

\section{Validation of research instruments}

The bilingual instrument was reviewed by five experts of Department of Education, University of Sargodha. In the light of experts' opinions, the research instrument was improved where necessary. After experts' review, it was administered on 60 students of BS program for pilot testing. These 60 students were not included in the sample. The results of pilot testing were analyzed and the internal consistency of the instrument in terms of Cronbach alpha was 0.759 . Factor-wise reliability coefficients for each factor were also calculated which were in acceptable range such as social information processing $=0.71$, social skills $=.73$ and social awareness $=0.76$. 


\section{Data Collection and Analysis}

The data was collected through self-approach. In June, before the end of session, data was collected from $1^{\text {st }}$ and $7^{\text {th }}$ semester students. Before distributing the research instrument, students were briefed for the importance of research and they were assured that their responses would be used for research purpose only and will be not shared with anyone. Total 560 questionnaires were distributed to students of $1^{\text {st }}$ and $7^{\text {th }}$ semester, the received questionnaires were 420 ; so, the response rate was $75 \%$

Percentage, mean scores, standard deviation and t-test was applied to analyze the data through software 'Statistical Package for Social Sciences' (SPSS) version 22.

Table 1

Students' Level of Social Intelligence

\begin{tabular}{|c|c|c|c|c|c|c|c|}
\hline $\begin{array}{l}\text { Level of } \\
\text { SI }\end{array}$ & $\begin{array}{l}\text { Mean } \\
\text { Value }\end{array}$ & $\begin{array}{l}1^{\text {st }} \\
\text { Semester }\end{array}$ & Percentage & $\begin{array}{l}7^{\text {th }} \\
\text { Semester }\end{array}$ & Percentage & Total & Percentage \\
\hline Low & $\leq 2.5$ & 74 & $33.8 \%$ & 17 & $8.46 \%$ & 91 & $21.66 \%$ \\
\hline Medium & $\begin{array}{l}2.6- \\
2.99\end{array}$ & 136 & $62.10 \%$ & 56 & $27.86 \%$ & 192 & $45.71 \%$ \\
\hline High & $\begin{array}{l}3.0- \\
3.5\end{array}$ & 8 & $3.65 \%$ & 88 & $43.8 \%$ & 96 & $22.85 \%$ \\
\hline Higher & $\geq 3.60$ & 1 & $0.46 \%$ & 40 & $19.90 \%$ & 41 & $9.76 \%$ \\
\hline
\end{tabular}

Table 1 shows the students' level of social intelligence (SI). There were 219 respondents from $1^{\text {st }}$ semester while 201 respondents were from $7^{\text {th }}$ semester. Four level of SI were considered i.e. low, medium high and higher. For low level the mean value 2.5 or less than that were taken. The value ranging from 2.6 to 2.99 were taken for medium level and for high level the mean value ranged $3.00-3.50$ and for higher level the mean value considered was 3.60 or greater.

There were $21.6 \%$ students with low level of social intelligence (SI) including $33.8 \%$ of first semester and $8.46 \%$ of semester seven. The students with medium levels SI were $45.7 \%$ including $62 \%$ students of $1^{\text {st }}$ semester and $27.8 \%$ of $7^{\text {th }}$ semester. In high level of SI, there were $22.85 \%$ students in which $3.65 \%$ students were of $1^{\text {st }}$ semester and $43.8 \%$ were of $7^{\text {th }}$ semester. Only $9.76 \%$ student had highest level SI in which only $0.46 \%$ student were from $1^{\text {st }}$ semester and $9.76 \%$ students were of $7^{\text {th }}$ semester. Overall majority of the students $68.5 \%$ from both $1^{\text {st }}$ and $7^{\text {th }}$ 
semester had the medium or high level of social intelligence ranging from 2.5 to 3.5 . While majority of $7^{\text {th }}$ semester students $(63.7 \%)$ had high or higher level of social intelligence as compared to students of $1^{\text {st }}$ semester majority $(96 \%)$ of those had medium or low level of social intelligence.

Table 2

Difference of Social Intelligence between Students of $1^{\text {st }}$ and $7^{\text {th }}$ Semester

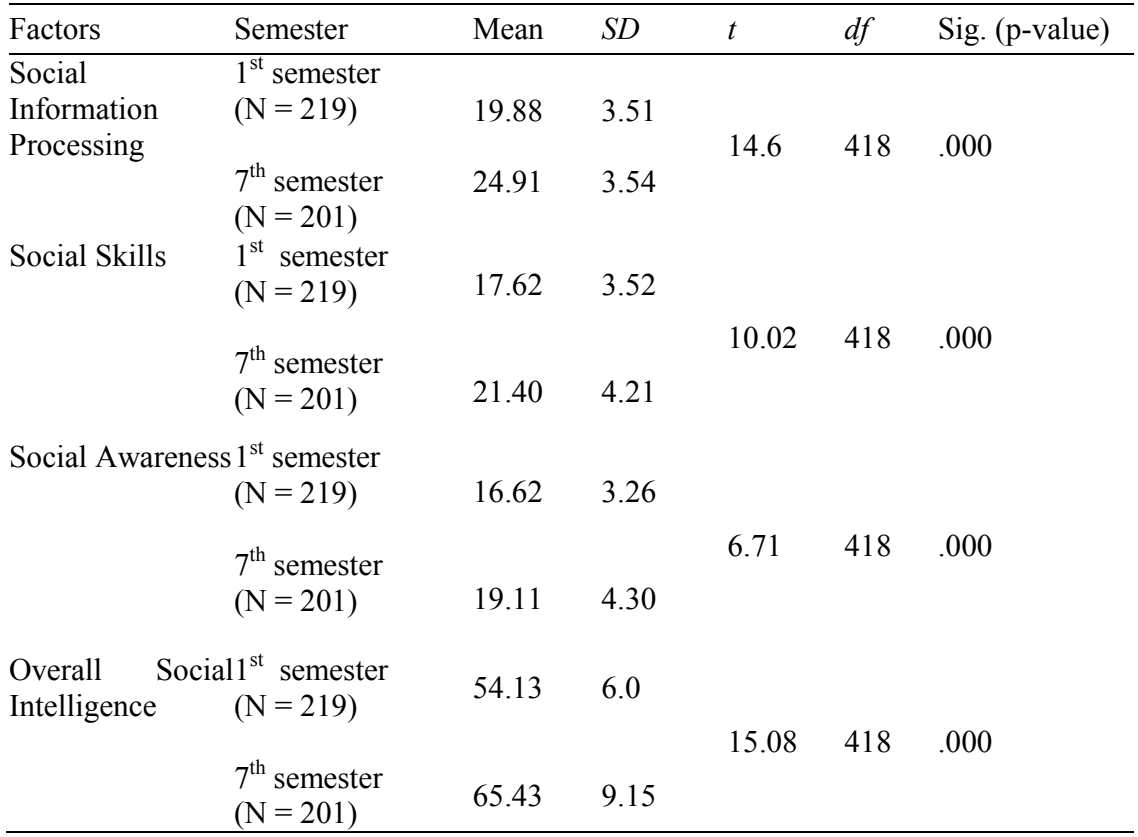

Table 2 depicts that there was significant difference of social intelligence (SI) among the students of $1^{\text {st }}$ and $7^{\text {th }}$ semester of BS program as indicated by $t$-value $=15.08$ with $d f=418$ and $p$-value $=$ $0.000<0.05$. The null hypothesis $\mathrm{H}_{01}$ was rejected and the greater mean score of students of $7^{\text {th }}$ semester $(M=65.43)$ shows the better level of SI than the students of $1^{\text {st }}$ semester with mean score $=54.13$. Similarly factor wise analysis revealed that there was significant difference among the students of $1^{\text {st }}$ semester and $7^{\text {th }}$ semester with respect to social information processing $(t$-value $=14.6$ with $d f=418$ and $p$-value $=$ $0.000<0.05)$, social skills $(t$-value $=10.02$, with $d f=418$ and $p$-value $=$ $0.000<0.05)$ and social awareness $(t$-value $=6.71$, with $d f=418$ and $\mathrm{p}$ value $=0.000<0.05$ ) 
The students of $7^{\text {th }}$ semester with greater mean scores $(24.91,21.40$ $\&$ 19.11) for entire three factors (i.e. social information processing, social skills and social awareness) were ahead of $1^{\text {st }}$ semester students with mean scores $(19.88,17.62 \& 16.62$ respectively).

Table 3

Difference of Social Intelligence among Male and Female Students of $1^{\text {st }}$ and $7^{\text {th }}$ Semester

\begin{tabular}{lllllll}
\hline Factors & Gender & Mean & $S D$ & $t$ & $d f$ & Sig.(p-value) \\
\hline $\begin{array}{l}\text { Social } \\
\text { Information }\end{array}$ & $\begin{array}{l}\text { Male } \\
\text { Processing }\end{array}$ & 22.11 & 4.42 & & & \\
Social Skills & $\begin{array}{l}\text { Female } \\
(\mathrm{N}=183)\end{array}$ & 22.52 & 4.20 & -.964 & 418 & .363 \\
& $\begin{array}{l}\text { Male } \\
(\mathrm{N}=237)\end{array}$ & 19.96 & 4.10 & & & \\
& $\begin{array}{l}\text { Female } \\
(\mathrm{N}=183)\end{array}$ & 18.74 & 4.46 & 2.91 & 418 & $.004^{* *}$ \\
Social & $\begin{array}{l}\text { Male } \\
\text { Awareness }\end{array}$ & 18.26 & 4.18 & & & \\
& $\begin{array}{l}\text { Female } \\
(\mathrm{N}=183)\end{array}$ & 17.23 & 3.65 & & & \\
Total & $\begin{array}{l}\text { Male } \\
(\mathrm{N}=237)\end{array}$ & 60.34 & 9.80 & & & $.008^{* *}$ \\
& $\begin{array}{l}\text { Female } \\
(\mathrm{N}=183)\end{array}$ & 58.50 & 9.07 & & & \\
& & & & & & \\
\end{tabular}

Table 3 shows that there were 237 male and 183 female students. In the factor of social information processing, the mean score of male students $(M=22.11)$ was almost equal to the mean score of the female students $(M=22.52)$, this difference was statistically not significant as indicated by $t$-value $=-.964$ with $d f=418$ at $\mathrm{p}=.363>0.05$. Further, for social skills, there was significant difference between the male and female students as indicated by $t=2.91$ with $d f=418$ and $\mathrm{p}$-value $=$ $0.004<0.05$. The higher mean score $(M=19.96)$ shows that the male students had better social skills than then female students with mean score $(M=18.74)$. Similarly, there was significant difference of social awareness between male and female students as indicated by $t$-value $=$ 2.64 with $d f=418$ and $p$-value $=0.008<0.05$. The greater mean score $(M=18.26)$ shows that male students were ahead in social awareness than the female students with mean score $=17.23$. In the factor of social 
information processing, male and female students were equal while in other two factors i.e. social skills and social awareness, male students were better than female students.

Overall, there was significant difference between the social intelligence of male and female students as indicated by $t$-value $=1.973$ with $d f=418$ and $p$-value $=.049<0.05$. So, the null hypothesis $\mathrm{H}_{02}$ was rejected and the higher mean score $(M=60.34)$ shows that male students have better social intelligence than the female students with mean score $(M=58.50)$.

Table 4

Difference of Social Intelligence between Boarder and Day Scholar Students

\begin{tabular}{lllllll}
\hline Factors & & Mean & $S D$ & $t$ & $d f$ & Sig. (p-value) \\
\hline $\begin{array}{l}\text { Social } \\
\text { Information }\end{array}$ & $\begin{array}{l}\text { Boarder } \\
\text { Processing }\end{array}$ & 22.11 & 4.33 & & & \\
Social Skills & $\begin{array}{l}\mathrm{N} \text { Day Scholar } \\
(\mathrm{N}=196)\end{array}$ & 22.53 & 4.31 & .984 & 410 & .326 \\
& $\begin{array}{l}\text { Boarder } \\
(\mathrm{N}=224)\end{array}$ & 19.36 & 4.14 & & & \\
& $\begin{array}{l}\text { Day Scholar } \\
\text { Boarder }\end{array}$ & 19.50 & 4.56 & .312 & 410 & .755 \\
Social & $\begin{array}{l}\text { (N=224) } \\
\text { Awareness }\end{array}$ & 17.77 & 4.04 & & & \\
& $\begin{array}{l}\text { Day Scholar } \\
(\mathrm{N}=196)\end{array}$ & 17.86 & 3.90 & .227 & 410 & .821 \\
Total & $\begin{array}{l}\text { Boarder } \\
(\mathrm{N}=224)\end{array}$ & 59.89 & 9.48 & & & \\
& Day Scholar & 59.25 & 9.69 & .680 & 410 & .497 \\
\hline
\end{tabular}

Table 4 shows that 224 students were boarder while 196 students were day scholar. The mean score of day scholar students $(M=22.53$ with $\mathrm{SD}=4.33$ ) was almost equal to the mean score of the boarder students $(M=22.11$ with $\mathrm{SD}=4.31)$ for social information processing and this difference was statistically not significant as indicated by $t$-value $=$ $.984)$ with $d f 410$ at $p$-value $=.326>0.05$. Furthermore, for social skills, the mean of day scholar students $(M=19.50$ with $\mathrm{SD}=4.56)$ was almost equal to the mean of the boarder students $(M=19.36$ with $\mathrm{SD}=4.14)$ and this difference was not statistically significant as indicated by $t$-value $=$ $.312, d f=410$ at $p=.755>0.05$. The same statistically insignificant difference of social awareness was found between the mean scores of 
boarder students $(M=17.86$ with $\mathrm{SD}=3.90)$ and day scholar students $(M$ $=17.77$ with $\mathrm{SD}=4.04)$ as indicated by $t$-value $=.227, d f=410$ and $p$ value $=.821>0.05$. As far as the total scale of social intelligence was concerned, the mean score of the day scholar students $(M=59.25$ with $\mathrm{SD}=9.69)$ was slightly greater than the mean score of the boarder students $(M=59.89$ with $\mathrm{SD}=9.48)$ but the $\mathrm{t}$-value $.680, d f=410$ and $p$ value $=.497>0.05$ concluded that the difference was not significant. So, the null hypothesis $\mathrm{H}_{03}$ was accepted which states that "there is no significant difference between the social intelligence of boarder and day scholar students".

Table 5

Difference of Social Intelligence between Rural and Urban Students

\begin{tabular}{|c|c|c|c|c|c|c|}
\hline Factors & & Mean & $S D$ & $\mathrm{t}$ & $d f$ & Sig.(p-value) \\
\hline $\begin{array}{l}\text { Social } \\
\text { Information }\end{array}$ & $\begin{array}{l}\text { Rural } \\
(\mathrm{N}=212)\end{array}$ & 21.95 & 4.38 & \multirow{3}{*}{1.533} & \multirow{3}{*}{415} & \multirow{3}{*}{.126} \\
\hline \multirow[t]{2}{*}{ Process } & & & & & & \\
\hline & $\begin{array}{l}\text { Urban } \\
(\mathrm{N}=208)\end{array}$ & 22.60 & 4.27 & & & \\
\hline \multirow[t]{2}{*}{ Social Skills } & $\begin{array}{l}\text { Rural } \\
(\mathrm{N}=212)\end{array}$ & 19.21 & 4.15 & \multirow{2}{*}{1.032} & \multirow{2}{*}{415} & \multirow{2}{*}{.303} \\
\hline & $\begin{array}{l}\text { Urban } \\
(\mathrm{N}=208)\end{array}$ & 19.65 & 4.46 & & & \\
\hline \multirow[t]{2}{*}{$\begin{array}{l}\text { Social } \\
\text { Awareness }\end{array}$} & $\begin{array}{l}\text { Rural } \\
(\mathrm{N}=212)\end{array}$ & 17.69 & 4.20 & \multirow{2}{*}{.579} & \multirow{2}{*}{415} & \multirow{2}{*}{.563} \\
\hline & $\begin{array}{l}\text { Urban } \\
(\mathrm{N}=208)\end{array}$ & 17.91 & 3.76 & & & \\
\hline \multirow[t]{2}{*}{ Total } & $\begin{array}{l}\text { Rural } \\
(\mathrm{N}=212)\end{array}$ & 58.85 & 9.99 & \multirow{2}{*}{1.407} & \multirow{2}{*}{415} & \multirow{2}{*}{.160} \\
\hline & $\begin{array}{l}\text { Urban } \\
(\mathrm{N}=208)\end{array}$ & 60.17 & 9.00 & & & \\
\hline
\end{tabular}

Table 5 shows that there were 212 students were from rural areas while 208 students were from urban areas. There was not statistically significant difference between the social information processing of the rural $(M=21.95, \mathrm{SD}=4.38)$ and urban areas $(M=22.60, \mathrm{SD}=4.27)$ students as indicated by $t$-value $=1.533, d f=415$ and $p$-value $=.126$ $>0.05$. Furthermore, for social skills, the mean of urban students (19.65, $\mathrm{SD}=4.46)$ was almost equal to the mean of the rural students (19.21, $\mathrm{SD}=4.15$ ) but this difference was statistically insignificant as indicated 
by $t=1.032, d f=415$ and $p=.303>0.05$. The same statistically insignificant difference of social awareness was found between rural areas students $(M=17.69 \& \mathrm{SD}=4.20)$ and urban area students $(M=$ $17.91 \& \mathrm{SD}=3.76)$ as indicated by $\mathrm{t}$-value $=.579, d f=415$ and $p=.563>$ 0.05 . As far as the total scale of social intelligence was concerned, the mean score of the urban area students $(M=58.85 \& \mathrm{SD}=9.99)$ was slightly lesser than the mean score of the rural area students $(M=60.17 \&$ $\mathrm{SD}=9.00)$ but the $t$-value $=1.407, d f=415$ and $p$-value $=.160>0.05$ concluded that this difference was not significant. So the null hypothesis $\mathrm{H}_{04}$ was accepted which states that "there is no significant difference between the social intelligence of urban and rural areas students".

\section{Conclusions}

Majority of the BS program students from both $1^{\text {st }}$ and $7^{\text {th }}$ semester had the medium or high level of social intelligence while students of $7^{\text {th }}$ semester had high or higher level of social intelligence as compared to students of $1^{\text {st }}$ semester who had medium or low level of social intelligence. The students of $7^{\text {th }}$ semester were ahead of $1^{\text {st }}$ semester students in entire three factors i.e. social information processing, social skills and social awareness. Male students have better social intelligence than the female students. In the factor of social information processing, male and female students were equal while in other two factors i.e. social skills and social awareness, male students were better than female students. Moreover there is no significant difference between the social intelligence of boarder and day scholar students as well as urban and rural areas students.

\section{Discussion}

The main purpose of the study was to explore the development of social intelligence during university years. The study found that social intelligence of students has significantly improved during university years as students of $7^{\text {th }}$ semester show high or higher level of social intelligence as compared to students of $1^{\text {st }}$ semester who have medium or low level of social intelligence. The findings are in line with the study of Ahmad, Jelas and Kassim (2013) which was a survey entitled "Social Intelligence of the Indigenous Pupils" and was conducted on sample of 150 of Year six (6) students in five schools of Malaysia and found that level of social intelligence competency was high among students. 
This study found that male students reported better social intelligence than female students. The findings of the study of Pramanik, Saha and Mondal (2014) are in line with findings of this study. But the studies of Kundu, Saha and Mondal (2015) and Nagra (2014) found that there exist no significant differences in the perceptions of male and female students regarding their social skills. Both of these studies were conducted in the Indian background. The possible reason behind these contradicting results might be due to the female roles in their respective cultures and societies. In Pakistan, women are less exposed to social settings than their male counterparts due to traditional and religious parda system and thus have less social intelligence.

Furthermore, the study found that there was no significant difference in the opinion of boarder students and day scholars, and rural and urban students regarding their social intelligence. The findings of the study of Nazir, Tasleema and Ganai (2015) contradict the findings of this study. They found that the urban college students have better social intelligence than the students of rural background. The possible reason of this contradiction might be the fact that Central Punjab has the most literacy rate in the country and the gap between rural and urban populations has diminished with the passage of time. This diminishing gap has reduced their exposure to national and international community especially with widespread of internet and modern means of communication. Moreover, Sargodha is not a big city and it is surrounded by many villages, the students of Sargodha University are more from the villages than the students of city that's why there is no significant difference among the students of Boarders and day scholars as well as among urban and rural students.

\section{Recommendations}

Following recommendations were made on the basis of findings and data analysis of the study:

The major missing aspect of our existing education system is the effective development of an individual that's why the students of BS reported that they hurt others without realizing it. The development of manners among students can be developed through education in institutions. So, it is recommended that a course or some units in any course about civic education may be incorporated by the course developers and academic councils. 
University teachers and BS students may be exposed towards social media, seminars, group discussion and co-curricular activities to provide confidence and to enhance their knowledge on the general topics. It will enhance their social information process, social skills and social awareness. 


\section{References}

Ahmad, A. R., Jelas, Z. M., \& Kassim, Z. (2013). Social Intelligence of the Indigenous Pupils. Australian Journal of Basic and Applied Sciences, 7(8).

Buzan, T. (2002). The power of social intelligence: 10 ways to tap into your social genius. New York: Thorsons.

Davis, J., (2010). The first generation student experience: Implications for Campus Practice, and Strategies for Improving Persistence and Success. Virginia: Stylus Publishing,

Dodge, K. A., \& Pettit, G. S. (2003). A bio-psychosocial model of the development of chronic conduct problems in adolescence. Developmental Psychology, 39, 349-371.

Dong, Q., Koper, R. J., \& Collaco, C. M. (2008). Social intelligence, self-esteem, and intercultural communication sensitivity. Intercultural Communication Studies, 17(2), 162-172.

Gini, G. (2006). Brief report: Adaptation of the Italian version of the Tromso social intelligence scale to the adolescent population. Journal of Adolescence, 29, 307-312.

Habib, S., Saleem, S., \& Mahmood, Z. (2013). Development and validation of social intelligence scale for university students. Pakistan Journal of Psychological Research, 28( 1), 65-83

Hopkins, M. M., \& Bilimoria, D. (2008). Social and emotional competencies predicting success for male and female executives. Journal of Management Development, 27(1), 13-35. Retrieved from, psycnet.apa.org/psycinfo/2008-05356-002

Kundu, M., Saha, B., \& Mondal, B. C. (2015). Adjustment of undergraduate students in relation to their social intelligence. American Journal of Educational Research, 3(11), 1398-1401.

Lacanlale, E. P. (2013). Development and validation of a social intelligence inventory. International Journal of Information and Education Technology, 3(2).

Laird, R. D., Jordan, K., Dodge, K. A., Pettit, G. S., \& Bates, J. E. (2001). Peer rejection in childhood, involvement with antisocial peers in early adolescence, and the development of externalizing 
problems. Development and Psychopathology, 13, 337-354. doi:10.1017/S0954579401002085.

Lease, A. M., Kennedy, C. A., \& Axelrod, J. L. (2002). Children's social constructions of popularity. Social Development, 11, 87-109. doi:10.1111/1467-9507.00188

Nagra, V. (2014). Social Intelligence and Adjustment of Secondary School Students. PERIPEX-Indian Journal of Research, 3(4), 86-87.

Nazir, A., Tasleema, D., \& Ganai, M. Y. (2015). Social intelligence and academic achievement of college students - A study of district Srinagar. IOSR Journal of Humanities and Social Science, 20(2), 7476. doi: 10.9790/0837-20227476

Parker, J. D., and Duffy, J, M., (2005). Making successful transition during the first year of College: Does emotional intelligence Matter? Journal of the First- Year Experience \& Students in Transition, 17(1), 67-78.

Praditsang, M., Hanafi, Z., \& Walters, T. (2015). The Relationship among Emotional Intelligence, Social Intelligence and Learning Behaviour. Asian Social Science, 11(13).

Pramanik, J, Saha, B. \& Mondal, B.C. (2014). Adjustment of Secondary School Students with Respect to Gender and Residence, American Journal of Educational Research, 12(2), 1138-1143.

Qualter, P., Whiteley, H., Morley, A. \& Dudiak, H., (2009). The role of Emotional Intelligence in the decision to persist with academic studies in HE. Research in Post Compulsory Education, 14, 219231. doi:10.1080/13596740903139255

Robert, S. Wyer, Jr., \& Srull, T. K. (2013). Social Intelligence and Cognitive Assessments of Personality. Advances in Social Cognition. New Jersey: Lawrence Erlbaum Associate Publishers.

Ryan, A., \& Patrick, H. (2001). The classroom social environment and changes in adolescents' motivation and engagement during middle school. American Educational Research Journal, 38(2), 437-460. doi: $10.3102 / 0002831203800243$

Seal, C. R., Naumann, S. E., Scott, A. N., \& Davis, J. R., (2011). Social emotional development: A new model of student learning in higher education. Research in Higher Education Journal,10, 1-13. 
Silvera, D. H., Martinussen, M., \& Dahl, T. I. (2001). The Tromso social intelligence scale, a self-report measure of social intelligence. Scandinavian Journal of Psychology, 42, 313-319. doi/10.1111/1467-9450.00242/abstract

Sternberg, R. J. (2004). Handbook of intelligence. Cambridge, U. K.: Cambridge University Press.

Wang, Y., \& Ollendick. T. H. (2001). A cross-cultural and developmental analysis of self-esteem in Chinese and Western children. Clinical Child and Family Psychology Review, 4(3), 253271.

Zins, J., Bloodworth, M., Weissberg, R., \& Walberg, H. (2004). The scientific base linking social and emotional learning to school success. Journal of Educational and Psychological Consultation, 17(2\&3), 191-210. http://dx.doi.org/10.1080/10474410701413145

\section{Citation of this Article:}

Malik, M. A., Siddique, F., \& Hussain, S.N. (2018). Exploring the development of social intelligence of students during university years.

Pakistan Journal of Education, 35(1), 43-58.

Received on: July $\quad 04,2017$

Revised on: February 02, 2018

Accepted on: March $\quad 22,2018$ 